DOI: https://doi.org/10.32838/2523-4803/70-6-34

УДК $336.02 ; 336.64 ; 336.77 .067 ; 368.01$

\title{
Стецько М.В.
}

доктор економічних наук, доцент,

доцент кафедри фінансового менеджменту та страхування,

Західноукраїнський національний університет

ORCID: https://orcid.org/0000-0002-7728-9178

\section{Боднар T.I.}

викладач циклової комісії з управління та адміністрування,

Калуський фаховий коледж економіки, права та інформаційних технологій

Івано-Франківського національного технічного університету нафти і газу

\section{Савіцька Л.В.}

викладач циклової комісії з управління та адміністрування,

Калуський фаховий коледж економіки, права та інформаційних технологій

Івано-Франківського національного технічного університету нафти і газу

\section{Stetsko Mykola}

West Ukrainian National University

Bodnar Tatyana, Savitska Lesya

Professional College of Economics, Law and Information Technologies

of Ivano-Frankivsk National Technical University of Oil and Gas

\section{ТЕНДЕНЦІЇ ТА СУПЕРЕЧНОСТІ У ФІНАНСОВОМУ ЗАБЕЗПЕЧЕННІ КОРПОРАТИВНОГО СЕКТОРУ ВІТЧИЗНЯНОЇ ЕКОНОМІКИ}

У роботі обтрунтовано необхідність формування ефективної моделі ринку капіталів, що забезпечує фінансування компаній реального сектору на основі принциипів інноваційного розвитку. Доведено, що краӥни з незбалансованою структурою фінансового сектору загалом страждають також від невідповідності структури наданих фінансових послуг. Аргументовано, щьо для забезпечення ефективного розвитку національного ринку капіталів необхідно визначитися з його глобальною метою та основним призначенням. Визначення його мети дозволить забезпечити єдність системи та внутрішні стимули для розвитку, пришвидиити інтеграцію у світову фінансову систему та синхронізувати внутрішні інтереси агентів ринку капіталів із інтересами реального сектору економіки. Обгрунтовано, щяо ринок капіталів в Україні, будучи иілісною соиіоекономічною системою, не має чіткої структурної організації своїх сегментів порівняно з корпоративними підприємствами. Запропоновано, щзо вирішення проблем розвитку ринку капіталів в Украӥні необхідно розглядати в тісному взаємозв'язку із питаннями корпоративного розвитку в реальній економіці.

Ключові слова: компанії реального сектору; структура фінансового ринку; ринок капіталів; модель ринку капіталів; модель кредитного ринку; управління і регулювання ринку капіталів.

Постановка проблеми. У контексті глобалізації економічних процесів, загострення проблеми залучення фінансових ресурсів та посилення ризиків, особливого значення набуває використання новітніх технологій прийняття фінансових рішень, зокрема рішень щодо залучення капіталу корпоративними підприємствами. Глобалізація надає для суб'єктів господарювання на ринку капіталів певні додаткові шанси. Водночас необхідно враховувати додаткові ризики, які пов'язані з можливими непередбачуваними зовнішніми впливами.

Використання наданих шансів і нейтралізація можливих ризиків обумовлюють необхідність проведення ретельного аналізу позитивних та негативних тенденцій розвитку вітчизняного фінансового ринку під впливом процесів глобалізації. Ключовими сегментами фінансового ринку в процесі фінансового забезпечення корпоративних підприємств $є$ ринок капіталів та кредитний ринок. Виходячи 3 результатів дослідження наукових праць та світової практики можна констатувати, що структура сучасного фінансового ринку визначається співвідношенням між зазначеними сегментами. Відповідне співвідношення визначає взаємозв'язок рівня розвитку ринку капіталів, корпоративного сектору економіки та їхні перспективи. У цьому зв'язку, непересічної актуальності набуває потреба в удосконаленні теоретико-методологічних підходів до вирішення питань взаємозв'язку ринку капіталів та корпоративного сектору через призму вибору моделі розвитку фінансового ринку.

Аналіз останніх наукових досліджень та публікацій. В останні роки в Україні з'явилась велика кількість наукових публікацій $з$ питань стратегії розвитку фінансового ринку та його взаємозв'язків 3 корпоративним сектором економіки. Проблематиці розвитку 
фінансового ринку, i, зокрема, його складової - ринку капіталів приділяється значна увага у працях вітчизняних та зарубіжних вчених. Так, питання впливу фінансового ринку та окремих його сегментів на економічне зростання у розвинених країнах досліджені у працях: П. Ажіона [1], Т. Бека, Е. Деміргука-Канта, Р. Лівайна [2], Р. Голдсміта [3], Х. Казерера, С. Раппа [4]. Місце ринку капіталів та банківських фінансовокредитних установ у формування моделі фінансового ринку, висвітлені у працях: В. Зимовця, О. Терещенка [5], В. Федосова [6], І. Школьник [7]. Дослідження науково-практичних джерел у відповідній тематиці засвідчує, що наукові думки концентруються, як правило, на особливостях моделей фінансування корпоративного сектору, що має місце в економічно розвинених країнах, механізмах державного регулювання фінансового ринку та окремих його складових, питаннях формування та удосконалення інфраструктури фінансового ринку, напрямах регулювання та стимулювання розвитку ринку капіталів і банківської системи.

Усе це свідчить про те, що у наукових працях практично не приділяється достатньо уваги питанням фінансового забезпечення корпоративного сектору вітчизняної економіки та обгрунтуванню найбільш сприятливої моделі розвитку фінансового ринку для країн з перехідною економікою з огляду її можливого впливу на темпи економічного зростання в країні та їі глобальну конкурентоспроможність.

Формулювання цілей статті. Метою пропонованого дослідження є обгрунтування взаємозв'язків між розвитком ринку капіталів та активізацією корпоративного сектору вітчизняної економіки. Це питання тісно пов'язане із вибором адекватної моделі фінансового забезпечення вітчизняних корпоративних підприємств та їх здатності бути конкурентоспроможними.

Викладення основного матеріалу дослідження. Основна функція сучасної фінансової системи полягає в тому, щоб сприяти ефективному переміщенню фінансових ресурсів від економічних суб'єктів, які мають тимчасовий їх надлишок, до суб'єктів, які відчувають тимчасову потребу в таких ресурсах.

Головними складовими частинами фінансового ринку є кредитний ринок та ринок капіталів. Згідно 3 найбільш поширеним підходом, у фінансових системах національних держав переважають або операції комерційного банкінгу (кредитний ринок), або угоди 3 цінними паперами (ринок цінних паперів) на ринку капіталів. Структура національних фінансових ринків визначається співвідношенням між зазначеними складовими. Дослідження теоретичних напрацювань і світової практики фінансового забезпечення підприємств та відповідної структури фінансових ринків дозволяє виокремити дві усталені моделі ринку, відповідно до фінансування реального сектору економіки:

- англосаксонську (market-oriented - ринково-орієнтована), яка передбачає домінуюче використання коштів, залучених з використанням інструментів ринку (market based financial system - модель ринку капіталів) [3];
- континентальну європейську модель (bankoriented - банківсько-орієнтовану), за якою підприємства фінансуються переважно через залучення банківських кредитів (bank based financial system - модель кредитного ринку або банкоцентрична модель).

Результати здійсненого аналізу дають змогу зробити висновок, що різниця між цими моделями полягає в превалюючому механізмі мобілізації заощаджень і трансформації їх в реальний сектор: через систему ринків цінних паперів, перш за все первинних, у першому випадку; або безпосередньо через систему фінансового посередництва - у другому.

3 одного боку, ціла низка вчених, таких як Д. Даймонд [D. Diamond, 1984], Д. Стігліц [D. Stiglitz, 1985], P. Стульц [R. Stulz, 2002], а також інші, вважали, що банкоцентрична модель перевершує англосаксонську. Згідно з цим підходом, банківські установи виконують функцію зниження інформаційної асиметрії і вирішують проблему трансакційних витрат та ризиків, а тому банківсько-орієнтована модель має переваги 3 погляду збору інформації, оцінки вартості підприємства і забезпечення взаємовідносин з іншими компаніями [A. Gerschenkron, 1962; T. Opler, Sh. Titman, 1993; R. Rajan, L. Zingales, 1998].

3 іншого боку, такі науковці, як Б. Хольмстрем i Ж. Тіроль [В. Holmstrom, J. Tirole, 1993], Е. Венгер і К. Kacepep [Е. Wenger, C. Kaserer, 1998], дотримувалися протилежної думки, відстоюючи переваги ринково-орієнтованої системи. Вони стверджували, що пряме переміщення коштів знижує агентські витрати. Однак при цьому збільшуються витрати, які пов'язані з асиметрією інформації.

Внаслідок обговорення цієї теми в наукових колах на початку XXI століття було сформовано так загальну тенденцію: ринково-орієнтовані моделі $€$ ефективнішими (більш гнучкіші і з відносно меншими агентськими витратами). Проте вже в класичній праці Ф. Аллена і Д. Гейла [F. Allen, D. Gale, 2001] стверджується, що відповідь на це питання не таке однозначне. Хоч автори і схильні погоджуватися 3 тезою про відносно більш високу ефективність ринково-орієнтованої системи за критерієм їі внеску в економічне зростання, однак підкреслюють, що такий висновок $€$ результатом більш позитивного аналізу, ніж нормативного. Вони стверджують, що країни з найбільш розвиненою фінансової системою є, в більшості випадків, ринково-орієнтованими (зокрема, США і Великобританія), проте це не обов'язково свідчить про наявність причинно-наслідкового зв'язку.

Характерно, що у банківсько-орієнтованих моделях фінансового забезпечення економіки банківські фінансово-кредитні установи залишаються основним механізмом розподілу капіталу та інвестицій, тоді як у ринково-орієнтованих системах ринки цінних паперів є важливішими, ніж банківські установи, для необхідного фінансування підприємств. Континентальна Європа та Японія зазвичай вважаються банківськоорієнтованими системами, на відміну від ринкових 
систем, які мають перевагу в англосаксонських країнах. Хоча відмінності між банківськими та ринковими моделями останнім часом стають менш чіткими. Очевидно, що банківські установи стають все більш орієнтованими на ринок, особливо під час глобальних криз, а парадигма банківських та ринкових моделей розвитку в цей ж момент надає важливий інструмент для їхнього порівняння.

Більше того, банківське фінансування залишається пріоритетним джерелом фінансового забезпечення корпоративних підприємств, особливо в банківсько-орієнтованих моделях розвитку економік окремих країн. Окрім цього, в більшості країн ЄС відстежувалася тенденція зменшення банківського кредитування підприємств починаючи з 2009 року, тобто після глобальної фінансової кризи (найбільш відчутне було економічне падіння у банківсько-орієнтованих економіках). У зв'язку із положеннями Базеля III, банківським установам довелося скоротити свої баланси, щоб зміцнити свої позиції з капіталізації, і це було зроблено, особливо в сфері транскордонної діяльності. Фінансова криза (2020р.), яка пов'язана з пандемією (COVID-19) у світових масштабах довела недооцінку та потенційні можливості банківсько-орієнтованих економік.

Цим проблемам в свій час була приділена увага у науковій праці Р. Де Хааса та I. Ван Лелівельда [8]. Результати проведеного ними аналізу доводять, що багатонаціональним дочірнім банкам довелося сповільнити зростання кредитів майже втричі швидше, ніж національним (зокрема, це стосувалося дочірніх відділень банківських груп, які більше покладалися на оптове фінансування) [8].

Необхідно зазначити, що у країнах із домінуванням банківсько-орієнтованої моделі фінансового ринку процентні ставки за кредитами $є$ в певній мірі вищі, ніж у ринково-орієнтованій моделі. Крім того, за континентальної європейської моделі більшими є систематичні ризики, котрі супроводжуються досить сильною волатильністю обсягів кредитування. У період росту кредити видаються, у тому числі ризиковим позичальникам, що призводить до росту проблемної заборгованості та рецесії на кредитному ринку. У період кризи - навпаки, банки можуть відмовляти у кредитуванні ефективних проектів. Таким чином, модель кредитного ринку не завжди виконує функцію ефективної алокації капіталу, а сам ринок розвивається циклічно.

Як зазначають С. Науменкова та В. Міщенко, збитки у банківському секторі можуть збільшуватись, коли спаду передує кредитний бум, і це створює замкнуте коло: проблеми у фінансовому секторі починають сприяти спаду в реальному секторі економіки, що знову призводить до проблем у банківському секторі. 3 метою уникнення таких ситуацій, в доповнення до буферного капіталу введено поняття контрциклічного буферу капіталу, який повинен гарантувати, що банківський сектор нарощує свій захист капіталу під час кредитного зростання [9, с. 3-11].
Необхідно не залишати поза увагою, що капіталізація фондового ринку може просто відображати динаміку цін, а не ступінь фінансування підприємств капіталом, отриманим з фондового ринку. Розвиток нових емісій акцій після глобальної кризи 2008 року відрізнявся в різних країнах. Хоча нові емісії акцій зазнають значного зниження майже у всіх групах країн, крім країн Східної Свропи, вони почали з 2012 року відновлюватися в країнах СС з ринковою та банківською орієнтованістю.

Здійснене дослідження дає можливість стверджувати, що нині на теоретичному рівні між ученими в цих дискусіях досягнуто певне взаєморозуміння. Під час порівняння значної кількості національних фінансових систем було встановлено, що обидві моделі мають як переваги, так і недоліки.

Більше того, теоретичне взаємопорозуміння в поглядах окремих науковців та взаємодоповнюваність моделей фінансового сектору не знімає проблему пошуку прийнятного балансу між ринковим i банківським напрямами розвитку фінансової системи. $€$ очевидним, що якщо фінансова система знаходиться в нестабільному стані щодо оптимального співвідношення банко- і ринково-орієнтованості, то економічні суб'єкти отримують неповноцінний обсяг фінансових послуг, що спричиняє негативний вплив на економічну активність підприємств. Отже в обох сегментах, фінансових ринків і фінансових посередників, формується дисбаланс попиту і пропозиції, який може прийняти стійкий характер. Вірогідно, що в результаті, країни 3 незбалансованою структурою фінансового сектору в цілому, страждають і від невідповідності структури наданих фінансових послуг. Причому такі невідповідності не обов'язково безпосередньо пов'язані зі структурою фінансової системи, оскільки тип фінансової моделі не завжди відображає рівень розвитку країни в цілому.

Отже, критерієм класифікації будь-якої країни, відповідно до моделей фінансування економіки, є співвідношення капіталізації фондового ринку та загальної суми виданих банківських кредитів. Пріоритетна проблема, яку необхідно з'ясувати обгрунтовуючи доцільність імплементації будь-якої структури фінансового ринку, полягає у визначенні причинних зв'язків між визначеною моделлю фінансового ринку і темпами економічного зростання в країні та можливостях підвищення іiі конкурентоспроможності.

Вище наведені факти переконують в тому, що наукова проблема полягає у з'ясуванні структури фінансового ринку, яка б могла більше сприяти економічному зростанню країни (яка б модель фінансування підприємств повинна була в теперішніх обставинах домінувати). Результати досліджень Т. Бека, Р. Лівайна [2] та інших науковців доводять, що співвідношення складових фінансового ринку значною мірою залежить від рівня життя у країні. У багатьох країнах 3 невеликим рівнем доходів ринок капіталів та інституційних інвестицій $\epsilon$, як правило, незрілим. Із збільшенням рівня 
доходів можливий розвиток ринку капіталів (спершу зростає капіталізація ринку, а згодом і його ліквідність). Характерно, що на економічне зростання більше впливає ліквідність ринку капіталів, ніж його обсяг [2]. У контексті цієї закономірності, з нашої точки зору, повністю виправданою є обрана вітчизняним регулятором (НКЦПФР) стратегія, котра спрямована на підвищення вагомості ринку капіталів в Україні, а також на його очищення від фіктивних цінних паперів. Реалізована стратегія стала результатом вагомого скорочення обсягу корпоративних цінних паперів та операцій 3 ними на фондовому ринку і сформувала умови, які повинні підвищити рівень його ліквідності.

Національні вимоги до організації ринку капіталів розрізняються у різних країнах. В Україні в даний час не до кінця визначені концептуальні засади визначення та розвитку вітчизняного ринку капіталів. У проекті Закону України від 01.09.2017 р. № 7055 «Про ринки капіталів та регульовані ринки» міститься необхідне, на наше переконання, нове тлумачення терміну «ринки капіталів». 3 одного боку ринок капіталів, відповідно запропонованих нововведень, прирівнюється до ринку фінансових інструментів і включає в себе фондовий ринок та ринок деривативів. 3 іншого боку фондовий ринок прирівнюється до ринку цінних паперів, як сукупності учасників фондового ринку та правовідносин між ними щодо розміщення, обігу та обліку цінних паперів [10]. Сформований підхід до трактування ринку капіталів, на наш погляд, містить ряд недоліків. Крім того, з огляду на вище запропоновану аргументацію, вітчизняний ринок капіталів недоцільно прирівнювати до фондового ринку, а також $є$ дещо спірним ототожнення ринку капіталів і учасників цього ринку. У наукових працях, котрі присвячені подібним питанням, пропонуються різноманітні визначення терміну «ринок», проте жодне не прирівнює «ринок» до «сукупності його учасників».

Результати проведеного дослідження економічної природи ринку капіталів дають можливість сформулювати таке: під ринком капіталів необхідно розуміти складову частину фінансового ринку, яка характеризує сукупність фінансових відносин між учасниками ринку довгострокового капіталу, котрий залучається на основі емісії фінансових інструментів (корпоративних прав та боргових цінних паперів). Інститути ринку капіталів обслуговують емітентів цінних паперів, зокрема корпоративний сектор, та інвесторів 3 метою забезпечення узгодження попиту і пропозиції на довгостроковий капітал. До цього сегменту належать ринок акцій та довгострокові боргові інструменти ринку цінних паперів. На ринках провідних країн світу (англосаксонська модель фінансування) корпоративні підприємства більшу частку свого капіталу формують безпосередньо на ринку капіталів. Очевидно, що головне призначення ринку капіталів полягає в обслуговуванні фінансових та інвестиційних потреб корпоративних підприємств. Щоправда, на переконання В. Бабіченко, в Україні існують певні диспропорції у механізмах, котрі забезпечують зв'язок корпоративних фінансів та ринку капіталів. Причиною подібних деформацій, на його переконання, є як суб'єктивні стереотипи, сформовані на рівні корпоративних підприємств, так і недовіра учасників фондового ринку до корпоративних цінних паперів, як об'єкта інвестування [11, с. 43-46].

Якщо більш детально дослідити організаційну сутність національного ринку капіталів, то необхідно звернути увагу, що даний ринок володіє двоякими властивостями. 3 одного боку, це цілісна фінансова система, котра складається з взаємопов'язаних елементів, а з іншого - це середовище, що представляє собою сукупність зовнішніх умов, в яких реалізують свій фінансовий і економічний інтерес різні види власників, юридично і організаційно відокремлених.

Національний ринок капіталів як цілісна фінансова система являє собою сукупність елементів, що складається з економічних агентів, що діють в своїх приватних, державних та інтересах громадських інститутів, що регулюють ринок капіталів правовими і організаційними заходами в інтересах фінансового ринку в цілому, а також в інтересах системи більш високого рівня - держави. До числа елементів системи ринку капіталів входить також і так званий регулятор, який являє собою створену в межах національної фінансової системи - підсистему інститутів.

Подвійна природа національного ринку капіталів, 3 одного боку, ріднить його з підприємством. Обидва об'єкти є відносно відокремленими соціоекономічними системами, що мають індивідуальний вектор розвитку, певну місію, а також межу, що відокремлює дану систему від інших споріднених і забезпечують відносну незалежність іiі розвитку. 3 іншого боку, національний ринок капіталів має схожість 3 соціально-економічними середовищами, наприклад 3 правовим середовищем. Це означає, що до реформування ринку капіталів повинні бути застосовані спеціальні підходи: частково аналогічні до підходів, щодо забезпечення розвитку підприємств, які мають місце під час формування та розвитку соціоекономічних середовищ [12].

Національний ринок капіталів - відкрита система, межі якої проникні, а елементи внутрішнього середовища значною мірою схильні до впливу з боку зовнішніх сил. Але в той же час, наявність досить чітко позначених меж свідчить про відносну відособленість об'єкта від інших ринкових систем. Відособленість повинна бути притаманна національному ринку капіталів, але на різних етапах розвитку можливий різний рівень відособленості.

Розвиток національного ринку капіталів, як i окремо взятого підприємства, обумовлюється як внутрішніми процесами, так і зовнішніми чинниками. Водночас сприятливі зовнішні умови можуть тільки полегшити розвиток, але не зумовити його. Без внутрішнього цілеспрямованого руху ринкова система не відбудеться. Акцент у цьому разі робиться саме 
на цілеспрямованість. Цим, у свою чергу, пояснюється цей факт, що в процесі становлення і розвитку найбільш ефективних національних ринків капіталів обов'язково з'являлася якась глобальна мета, призначення національного ринку капіталів. Це призначення об'єднувало всі елементи ринку, що дозволяло їм діяти, як єдине ціле, по відношенню до зовнішніх чинників, а також здійснювати економічну співпрацю між собою, незважаючи на конкуренцію.

Таким чином, призначення - це один із базових елементів організації національного ринку капіталів. Роль призначення полягає в синхронізації інтересів контрагентів національного ринку капіталів і формуванні напрямку розвитку для системи загалом. Таке призначення повинно забезпечити розвиток системи відповідним чином, щоб:

- по-перше, внутрішня конкуренція економічних агентів не призводила до розвалу єдності системи i хаосу, а навпаки, створювала внутрішні стимули для розвитку системи;

- по-друге, регулювання ринку капіталів забезпечувало допустимий рівень прозорості кордонів, щоб не допустити крайнощів (їх закриття для переміщення капіталів і внаслідок цього відторгнення від світового ринку капіталів, або остаточного розмивання кордонів і передчасної інтернаціоналізації та глобалізації національного ринку капіталів);

- по-третє, регулювання ринку капіталів забезпечувало синхронізацію внутрішніх інтересів агентів ринку капіталів та інтересів реального сектору економіки.

Незбігання інтересів ринку капіталів та інтересів реального сектору економіки може спричинити формування фінансових бульбашок, i, як наслідок, кризових явищ.

Незважаючи на те, що двояка природа ринку ріднить його із звичайним підприємством, управління ринком капіталів зазвичай здійснюється за іншими моделями, на відміну від тих, які є загальноприйнятними в процесі управління компанією. Вірогідно, що ринку притаманні властивості соціоекономічного середовища, зокрема, непідконтрольність учасників даного ринку, а також відсутність лінійної підпорядкованості самих учасників регулюючим органам.

Будучи цілісною соціоекономічною системою, національний ринок капіталів водночас не має чіткої структурної організації своїх сегментів в порівнянні 3 корпоративними підприємствами. Ці факти переконливо доводять, що неможливо стверджувати про управління ринком капіталів, якщо під управлінням розуміти свідомий, цілеспрямований вплив з боку органів управління на учасників та економічні об'єкти, що в кінцевому рахунку забезпечує отримання запланованих результатів. Відповідний стан речей обумовлений самою природою ринку, суть якої полягає у вільних стосунки між учасниками з приводу купівлі-продажу та укладання торгових угод.

Результати проведеного дослідження підтверджують, що принципова відмінність регулюючих впливів ринку капіталів від дій, що управляють у межах підприємства, полягає в тому, що вектор управлінського впливу в межах підприємства переважно спрямований лінійно (від суб'єкта управління до об'єкта управління), а вектор регулюючого впливу на ринку капіталів спрямований лінійно тільки в тому разі, коли йдеться про законодавче регулювання. В цьому розумінні всі інші регулюючі дії не мають лінійної траєкторії від суб'єкта впливу до об'єкта.

Як підсумок, можна констатувати, що з одного боку ринкове середовище являє собою інституціональну інфраструктуру котра складається з державних і громадських організацій, які діють на основі прийнятої системи права, культурної та ділової традиції. 3 іншого боку воно покликане забезпечити можливість для кожного учасника-резидента системи, який бажає укласти угоду, рівні права та повноцінний захист його власного інтересу.

Усе це свідчить про те, що ринкове середовище повинно мати такі складові частини:

- визначену кількість учасників-партнерів, присутніх на ринку;

- певний рівень свободи учасників-партнерів для досягнення власних інтересів;

- відповідну інформаційну ефективність;

- рівень ризиків, на який погоджуються в угодах учасники-партнери;

- механізми та можливості впливу регулятора на процеси всередині системи і на зовнішні взаємовідносини.

Безсумнівно, що внаслідок своєї подвійності ринок капіталів володіє специфічним набором рис, які повинні бути враховані в процесах, що відбуваються на ньому та його регулюванні.

Висновки. Результати оцінки, відповідно до наведених підходів, дадуть змогу виявити взаємозв'язки та подолати суперечності в процесі фінансового забезпечення вітчизняного корпоративного сектору економіки та організації фінансового ринку. I, як наслідок, можна буде зробити висновки про найбільш ефективні підходи щодо організації національного ринку капіталів, розробити прийнятну для вітчизняної економіки модель розвитку та засоби іiі реалізації.

Таким чином, основні проблеми формування та розвитку ринку капіталів в Україні необхідно розглядати в тісному взаємозв'язку із проблемою корпоративного розвитку в реальній економіці, аналогічно, як i проблеми формування та розвитку корпоративного сектору повинні розглядатися в тісному взаємозв'язку iз проблемами становлення ринку капіталів.

Список літератури:

1. Aghion P., Howitt P. Mayer-Foulkes D. The Effect of Financial Development on Convergence : Theory and Evidence. Quarterly Journal of Economics. 2005. Vol. 120. P. 173-222. 
2. Beck Th., Demirgu-Kunt A., Laeven L., Levine R. Finance, Firm Size, and Growth. Journal of Money, Credit and Banking. 2008. Vol. 40 (7). P. 1379-1405.

3. Goldsmith R.W. Financial structure and development by Raymond W. Goldsmith. New Haven : Yale University Press, 1969. $561 \mathrm{P}$.

4. Kaserer C., Rapp S. Capital Markets Development in the European Union - LongTerm Trends, Economic Drivers and Policy Challenges. AIMA, Resear Report. March 2014. URL: http://www.europeanissuers.eu/_lib/newsflash/research_ paper_-_release_version___march_2014.pdf (дата звернення: 02.10.2020).

5. Зимовець В. В., Терещенко О. О. Корпоративні фінанси як домінанта фінансової науки. Фінанси України. 2015. № 9. С. 78-95.

6. Федосов В., Рязанова Н. Концептуальні питання теорії корпоративних фінансів. Ринок изіних паперів України. 2013. № 3-4. C. 39-55.

7. Школьник І.О. Роль банків у процесі формування національної моделі фінансового ринку. Вісник Української академії банківської справи. 2008. № 1 (24) С. 64-70.

8. De Haas, R.,I. Van Lelyveld. Multinational banks and the global financial crisis: Weathering the perfect storm? Journal of Money, Credit, and Banking. 2014. No. 46 (1), pp. 333-364.

9. Науменкова С.В., Міщенко В.І. Сучасні проблеми капіталізації банківської системи України. Фінансово-кредитна діяльність: проблеми теорії та практики. 2013. № 2 (15). С. 3-11.

10. Про ринки капіталу та регульовані ринки. Проект Закону України від 01.09.2017 p. № 7055. URL: https://ips.ligazakon.net/document/view/JH5FZ00A?an=3028\&ed=2017_09_01 (дата звернення: 21.10.2020).

11. Бабіченко В.В. Домінанта корпорацій в сучасній економіці: фінансові чинники. Інвестицї: практика та досвід. 2015. № 6. С. 43-46.

12. Залознова Ю.С. Соціоекономічний розвиток України в контексті глобальних і національних викликів : монографія. Київ : НАН України, Ін-т економіки пром-сті, 2014. 336 с.

\section{References:}

1. Aghion P., Howitt P. Mayer-Foulkes D. (2005) The Effect of Financial Development on Convergence: Theory and Evidence. Quarterly Journal of Economics, vol. 120, pp. 173-222.

2. Beck Th., Demirgu-Kunt A., Laeven L., Levine R. (2008) Finance, Firm Size, and Growth. Journal of Money, Credit and Banking, vol. 40 (7), pp. 1379-1405.

3. Goldsmith, R.W. (1969) Financial structure and development by Raymond W. Goldsmith. New Haven: Yale University Press.

4. Kaserer C., Rapp S. (2014) Capital Markets Development in the European Union - LongTerm Trends, Economic Drivers and Policy Challenges. AIMA, Resear Report. March 2014. Available at: http://www.europeanissuers.eu/_lib/ newsflash/research_paper_-_release_version_- march_2014.pdf (accessed 02 October 2020).

5. Zymovets V.V., Tereshchenko O. O. (2015) Korporatyvni finansy yak dominanta finansovoi nauky [Corporate finance as a dominant of financial science]. Finansy Ukrainy - Finance of Ukraine, no. 9, pp. 78-95. (in Ukrainian)

6. Fedosov V., Riazanova N. (2013) Kontseptualni pytannia teorii korporatyvnykh finansiv [Conceptual issues of corporate finance theory]. Rynok tsinnykh paperiv Ukrainy - Securities Market of Ukraine, no. 3-4, pp. 39-55. (in Ukrainian)

7. Shkolnyk I.O. (2008) Rol bankiv u protsesi formuvannia natsionalnoi modeli finansovoho rynku [The role of banks in the process of forming a national model of the financial market]. Visnyk Ukrainskoi akademii bankivskoi spravy - Bulletin of the Ukrainian Academy of Banking, no. 1 (24), pp. 64-70. (in Ukrainian)

8. De Haas R., Lelyveld I. (2014) Multinational banks and the global financial crisis: Weathering the perfect storm? Journal of Money, Credit, and Banking, no. 46 (1), pp. 333-364. (in Ukrainian)

9. Naumenkova S.V., Mishchenko V.I. (2013) Suchasni problemy kapitalizatsii bankivskoi systemy Ukrainy [Modern problems of capitalization of the banking system of Ukraine.]. Finansovo-kredytna diialnist: problemy teorii ta praktyky Financial and credit activities: problems of theory and practice, no. 2 (15), pp. 3-11. (in Ukrainian)

10. Pro rynky kapitalu ta rehulovani rynky. Proekt Zakonu Ukrainy [About capital markets and regulated markets. Draft Law of Ukraine]. Available at: https://ips.ligazakon.net/document/view/JH5FZ00A?an=3028\&ed=2017_09_01 (accessed 21 October 2020).

11. Babichenko V.V. (2015) Dominanta korporatsii v suchasnii ekonomitsi: finansovi chynnyky [The dominance of corporations in the modern economy: financial factors]. Investytsii: praktyka ta dosvid - Investytsiyi: praktyka ta dosvid, no. 6, pp. 43-46. (in Ukrainian)

12. Zaloznova Yu.S. (2014) Sotsioekonomichnyi rozvytok Ukrainy v konteksti hlobalnykh i natsionalnykh vyklykiv [Socio-economic development of Ukraine in the context of global and national challenges]. Kyiv: NAN Ukrainy, In-t ekonomiky prom-sti. (in Ukrainian) 


\section{ТЕНДЕНЦИИ И ПРОТИВОРЕЧИЯ В ФИНАНСОВОМ ОБЕСПЕЧЕНИИ КОРПОРАТИВНОГО СЕКТОРА ОТЕЧЕСТВЕННОЙ ЭКОНОМИКИ}

В работе обоснована необходимость формирования эффективной модели рынка капиталов, что обеспечивает финансирование компаний реального сектора на основе принципов инновационного развития. Доказано, что страны с несбалансированной структурой финансового сектора в целом страдают также от несоответствия структуры предоставляемых финансовых услуг. Аргументировано, что для обеспечения эффективного развития национального рынка капиталов необходимо определиться с его глобальной иелью и основньлм назначением. Определение его цели позволит обеспечить единство системы и внутренние стимуль для развития, ускорить интеграцию в мировую финансовую систему и синхронизировать внутренние интересов агентов рынка капиталов с интересами реального сектору экономики. Обосновано, что рынок капиталов в Украине, будучи иелостной социоэкономической системой, не имеет четкой структурной организаџии своих сегментов по сравнению с корпоративными предприятиями. Предложено, что решение проблем развития рынка капиталов в Украине необходимо рассматривать в тесной взаимосвязи с вопросами корпоративного развития в реальной экономике.

Ключевые слова: компании реального сектора, структура финансового рынка, рынок капиталов, модель рынка капиталов, модель кредитного рынка, управления и регулирования рынка капиталов.

\section{TENDENCIES AND CONTRADICTIONS IN FINANCIAL SUPPORT OF THE CORPORATE SECTOR OF THE DOMESTIC ECONOMY}

The paper substantiates the necessity to form an effective capital market model that provides financing for the companies of the real sector based on the principles of innovative development. The analysis of financial support models of domestic corporate enterprises and fields of capital market development in Ukraine was carried out, based on the experience of leading economically developed countries. The study substantiates that the countries with an unbalanced structure of the financial sector also suffer from inconsistencies in the structure of financial services. It is proved that the main problem that needs to be solved by substantiating the feasibility of implementing any structure of the financial market is to determine the causalities between a particular model of financial market and economic growth in the country, the possibility of increasing its competitiveness. The study proves that the significant problems of the national capital market are its information inefficiency, significant level of manipulation, low capitalization and liquidity, insecurity of investors' rights and poor quality of corporate management. It is proved that due to a number of subjective and objective reasons the national capital market was inefficient during the whole period of its functioning and practically did not perform its functions. The study argues that to ensure the effective development of the national capital market it is necessary to determine its global purpose and main objective. Defining its purpose will ensure the unity of the system and internal incentives for development accelerate integration into the global financial system and synchronize the internal interests of capital market agents with the interests of the real sector of the economy. It is substantiated that the capital market in Ukraine, being integral socio-economic system, does not have a clear structural organization of its segments in comparison with corporate enterprises. Based on this circumstance, it is impossible to argue about the management of the capital market, if the management is understood as a conscious, purposeful influence of the authorities on participants and economic objects, which ultimately ensures the expected results. It is suggested that solving the problems of capital market development in Ukraine should be analyzed in close connection with corporate development in the real economy, similarly, as problems of formation and development of the corporate sector should be considered in close connection with capital market formation.

Key words: companies of the real sector, capital market, financial market structure, market based financial system, bank based financial system, control and regulation of capital market. 